\begin{tabular}{c} 
Volume and Issues Obtainable at Center for Sustainability Research and Consultancy \\
Journal of Accounting and Finance in Emerging Economies \\
ISSN: 2519-0318 ISSN (E) 2518-8488 \\
Volume 3: Issue 1 June 2017 \\
CSRᄃ \\
Journal homepage: www.publishing.globalcsrc.org/jafee \\
\hline
\end{tabular}

\title{
Effect of Audit Committee Expertise and Meeting on Earnings Quality in Indonesian Listed Companies: A Conceptual Approach
}

\author{
${ }^{1}$ Lidya PrimtaSurbakti, ${ }^{2}$ Hasnah BintiShaari, ${ }^{3}$ Hasan Mohammed Ahmed Bamahros \\ ${ }^{1} \mathrm{PhD}$ Scholar, Department of TunkuPuteriIntanSafinaz School of Accountancy, Universiti Utara Malaysia, \\ Malaysia, lidyaprimtasurbakti@gmail.com \\ ${ }^{2}$ Lecturer, Department of TunkuPuteriIntanSafinaz School of Accountancy, Universiti Utara Malaysia, Malaysia, \\ s.hasnah@uum.edu.my \\ ${ }^{3}$ Lecturer, Department of TunkuPuteriIntanSafinaz School of Accountancy, Universiti Utara Malaysia, \\ Malaysia, hasanmohammed@uum.edu.my
}

\begin{tabular}{|c|c|}
\hline ARTICLEDETAILS & ABSTRACT \\
\hline History & Purpose: The purpose of this paper will focus on monitoring and improving \\
\hline Revised format: May 2017 & corporate governance through earnings quality. In particular, audit \\
\hline AvailableOnline: June 2017 & committee effectiveness is seen as a significant factor in ensuring effective \\
\hline Key & a conceptual framework that will examine the impact expertise, meeting and \\
\hline Audit Committee, & meeting attendance on the earnings quality of companies. \\
\hline Audit Committee E & Methodology:Future empirical studies could be conducted quantitatively \\
\hline Audit Committee Meeting, & with secondary data. The report from annual reports of companies listed in \\
\hline Earnings Quality & $\begin{array}{l}\text { Indonesia Stock Exchange (IDX) starting from the period of implementation } \\
\text { of the new code on implementation guideline in } 2013 \text {. }\end{array}$ \\
\hline JEL Classification: & Implication: In fact, the main issue was centered on financial reporting \\
\hline M4, L15 & $\begin{array}{l}\text { manipulations and there is need to examine and develop a mechanism that } \\
\text { in addition, agency theory is expected to explain the above three factors in } \\
\text { providing explanation to accounting information that relates to the earnings } \\
\text { quality under study. Finally, it is expected that future empirical studies with } \\
\text { this conceptual framework can enhance earnings quality for users of } \\
\text { financial statements such as: investors, creditors, shareholders and other } \\
\text { stakeholders in Indonesia and beyond. }\end{array}$ \\
\hline
\end{tabular}

(C) 2017 The authors, under a Creative Commons AttributionNonCommercial 4.0

Corresponding author's email address: lidyaprimtasurbakti@gmail.com

Recommended citation:Surbakti,L.P., Shaari,H.B. \&Bamahros,H.M.A., (2017).Effect of Audit Committee Expertise and Meeting on Earnings Quality in Indonesian Listed Companies: A Conceptual Approach. Journal of Accounting and Finance in Emerging Economies, 3(1) 47-54.DOI:https://doi.org/10.26710/jafee.v3i1.97

\section{Introduction}

The prolonged economic crisis in Asia which began from 1998 until early 2000 and the bankruptcy issues with big corporations in the US such as WorldCom, Tyco, Toshiba Corp, Enron, Lucent, and Xerox negatively affects the quality of earnings in companies. As such, financial scandals in financial statements distort the quality of financial reporting and by extension; such scandals affect the decision-making capabilities of stakeholders, especially in terms of being imprecise with decision-making processes (Chang \& Sun, 2010; Lau, 2014). According to Schipper and Vincent (2003), low earnings quality is capable of causing miscalculation of capital and other related resources by investors, and other users of 
financial statements.

Low earnings quality is a function of low performance of organizations which negatively affects investor confidence in the financial reporting of organizations (Luchs et al., 2009). Similarly, low earnings quality is a result of lack of transparency of financial reporting occasioned by weak laws and related legislations to protect investors as well as non-application of extant corporate governance principles and mechanisms (Dhaliwal et al., 2014; Donaggio, 2014; Fan \& Wong, 2002). On the other hand, good corporate governance helps in reducing agency costs by aligning the interests of owners and management (Jensen \&Meckling, 1976).

Asian countries are experiencing weak corporate governance and Indonesia is one of such countries (Asian Corporate Governance Association, 2014). This is because; Indonesia was reported to have low earnings quality as it was ranked as the $35^{\text {th }}$ out of 48 countries in the world (Milken Institute, 2009). Therefore, to improve the investment climates, it is pertinent to provide better protection for investors. One of such ways of protecting investors is by strengthening internal governance mechanisms. Additionally, based on the provisions of the agency theory, effectiveness of the audit committee will improve earnings quality and reduce agency problem (Baxter \& Cotter, 2009; Saenz Gonzales \& GarciaMeca, 2014).

In order to strengthen the audit committee functions, companies are required to report the percentage of meeting attendance of the audit committee member in the audit committee's performance report (BAPEPAM-LK, 2012). Also, attendance to audit committee meetings is important to its effectiveness in the financial reporting of organizations (Rickling, 2014). Audit committee members with expertise in accounting knowledge can facilitate the committee in monitoring the financial reporting process more effective (Sun et al., 2014). Particularly, audit committee is tasked to supervise the financial reporting process and as such, members with accounting and finance background meet more often to meeting issues of financial reporting so that it can withstand the practice of earnings management (Baxter \& Cotter, 2009). In a nutshell, effectiveness of audit committee can ensure financial reporting that is free of misstatement, resulting in reduce information asymmetry and enhanced earnings quality, and the building of better investors' confidence.

\section{Earnings Quality and Internal Monitoring of Corporate Governance}

Earnings quality of corporations cannot be separated from the agency conflict. When owner (principal) delegates decision-making authority to management (agent), it could have broader information than the owner (information asymmetry). Earnings quality is a very important factor for users of financial information such as investors, financial analysts, creditors, regulators and academics (Ghajara\&Saeidi, 2016; Nelson \& Skinner, 2013). According to Dechow et al. (2010) earnings quality is aimed at providing information about the features of a firm's financial performance that are relevant to a specific decision made by a specific decision-maker. Earnings quality information is expected to be relied upon in making investment decisions and in making the markets more efficient (Schipper\&Vincent, 2003; Wang et al., 2009). Therefore, to improve earnings quality, monitoring the financial reporting process to avoid financial scandals is of paramount importance (Chang \& Sun, 2010).

Earnings quality is critical to the financial reporting system. In improving the transparency of financial reporting, some efforts should be put in place. The efforts are amongst others: changes in accounting standards, corporate governance and external audit. More so, increases in financial transparency will greatly impact on the increase in earnings quality (Ewert\&Wagenhofer, 2013). Furthermore, earnings quality was found to be useful and relevant information for shareholders in predicting share return. Hence, earnings and future returns are expected to be related, and has been supported by some empirical underpinnings (Martínez-Ferrero et al., 2015). Thus, investors perceived that companies with high earnings quality are more transparent (Alves, 2014). 
Internal monitoring of corporate governance reduces the asymmetry of information between the management and the shareholders. However, this is a responsibility of the audit committee (Baxter \& Cotter, 2009; Rusmin, 2011). Agency theory is the basis of corporate governance through internal and external mechanisms (Roberts et al., 2005; Weir et al, 2002). With perspectives of agency theory, effectiveness of the audit committee can increase monitoring to protect the interests of shareholders and reduce agency cost and increase earnings quality (Adiguzel, 2013; Azzoz\&Khamees, 2016; McKnight \& Weir, 2009).

Audit committee is a monitoring unit in corporate governance and the main purpose of its existence is to protect the interests of shareholders and to perform its responsibilities in monitoring internal control, and financial disclosure accordingly (Turley \& Zaman, 2004). The provisions of the agency theory posit that the characteristics of the audit committee involves monitoring of the financial reporting standards of the organization to enhance effectiveness and thereby reduce asymmetric information and agency cost (Ika\&Ghazali, 2012; Qi \& Tian, 2012). The characteristics of audit committee include expertise, meeting, and meeting attendance (Bala\& Kumai, 2015; Musa et al., 2017; Sharma \&Kuang, 2014).

Accounting and finance expertise of audit committee members is critical to their effectiveness. Audit committee members with expertise in accounting knowledge can facilitate the committee in monitoring the financial reporting process more effectively (Sun et al., 2014). Similarly, audit committee meeting and meeting attendance are important to its effectiveness in the financial reporting of organizations (Baxter \& Cotter, 2009; Musa et al., 2017; Saleh et al., 2007; Yusof, 2010). Audit committee meeting and meeting attendance of members can make the audit committee to be more effective in monitoring the management in suppressing earnings management practice, reduce earnings manipulation (Musa et al., 2017) and reduce agency problem and thus, improving earnings quality (Jensen \&Meckling, 1976).

\section{The Conceptual Framework and hypothesis Development}

The conceptual framework of this study is developed to study the relationship of audit committee effectiveness with earnings quality. In this proposed framework, effectiveness of auditcommittee such as meeting, expertise and meeting attendance are the independent variables and earnings quality is the dependent variable. To emphasize, the present study tries to bridge the gap by giving a basis for a thorough and insightful investigation on the relationship between audit committee effectiveness and earnings quality. Figure 1 illustrates the link between effectiveness of the audit committee with earnings quality.

Figure 1: The Conceptual Framework of the Study

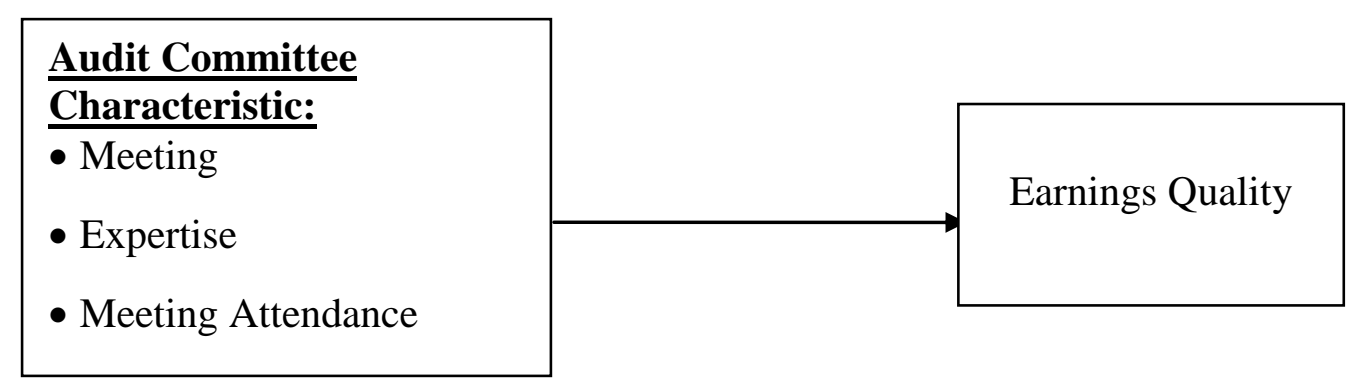




\subsection{Audit Committee Meeting and Earnings Quality}

Audit committee meeting is important in conducting effective oversight functions in monitoring the performance of managers (Bala\& Kumai, 2016; Soliman\&Ragab, 2014). Beasley (1996) suggested that audit committee meetings should at least be conducted once to review the interim report. This is because, high frequency of audit committee meeting tend to reduce financial problem (Menon \& Williams, 1994). Also, based on agency theory perspective, the results of previous studies have shown that frequency of audit committee meeting can improve earnings quality (Bamahros\&Wan-Hussin, 2011; Garcia et al., 2010; Yusof, 2010). Furthermore, several empirical studies have tested the relationship between the frequency of audit committee meeting and earnings quality and found positive significant results (Salleh\&Haat, 2014; Soliman\&Ragab, 2014; Garcia et al., 2010; Yusof, 2010). In contrast, other previous studies (Bala\& Kumai, 2015; Baxter \& Cotter, 2009; Chandrasegaram et al., 2013; Hamdam et al., 2013; Mohamad et al., 2012) have found insignificant relationship between audit committee meeting and earnings quality. Based on these finding the following hypothesis is proposed:

\section{H1: Frequency of audit committee meeting is positively related to earnings quality.}

\subsection{Audit Committee Expertiseand Earnings Quality.}

The audit committee oversees financial reporting and disclosure. Thus, audit committee member with accounting and finance background will aid in effective monitoring of management and the review of financial statements of a firm (Badolato et al., 2014) as well as in monitoring transfer pricing manipulations such as EM (Lo et al., 2010). When audit committee have members with requisite expertise in accounting and finance, the audit committee will be effective in monitoring and there will be good financial reporting. It will also limit opportunistic management and protect the interests of shareholders and stakeholders thereby reducing agency problems and enhance earnings quality (Badolato et al., 2014; Marra et al., 2011). Several studies have found significant positive relationships between audit committee expertise and earnings quality (Badolato et al., 2014; Marra et al., 2011; Salleh et al., 2007; Yusof, 2010). However, other past studies found insignificant relationships between audit committee expertise and earnings quality (Carcello et al., 2006; Hamdan et al., 2013; Lo et al., 2010).In view of the above submissions, the following hypothesis is postulated:

\section{H2: Audit committee expertise is positively related to earnings quality}

\subsection{Audit Committee Meeting Attendance and Earnings Quality.}

Audit committee members' meeting attendance is the percentage of audit committee members attending meetings in a year (Musa et al., 2017; Ormin et al., 2016). Ormin et al (2016) states that audit committee attendance to meeting is an evaluation of the performance of audit committee members. With more meeting attendance of audit committee members, there will be better monitoring of management activities especially in ensuring the integrity of financial statements (Vafeas, 1999). The presence of audit committee members is an important criterion in evaluating the performance of audit committees, because with the frequent presence of audit committee members, the audit committee is considered to be more effective (Ormin et al., 2016). On the other hand, some studies found that positive relationship between audit committee meeting attendance and earnings quality such as the works of Musa et al. (2017) and Ormin et al. (2016). Based on the above scenario, the following hypothesis is proposed:

\section{H3: Audit committee meeting attendance is positively related to earnings quality.}

\section{Proposed Method}

It is recommended that future empirical studies could be conducted quantitatively with secondary data. The report from annual reports of companies listed in Indonesia Stock Exchange (IDX) starting from the period of implementation of the new code on implementation guideline in 2013. It is further suggested that future empirical studies should target a sample of non-financial companies because these are the 
sectors that contributed significantly to domestic gross income in Indonesia.

Table 1: Non-financial Companies Listed in IDX

\begin{tabular}{lc}
\hline Sector & Number of companies \\
\hline Agricultural sector & 21 \\
Mining sector & 28 \\
Basic and chemical sector & 61 \\
Various industry sector & 41 \\
Consumer goods industry sector & 37 \\
Property, real estate and building construction sector & 61 \\
Infrastructure, utilities and transport sector & 57 \\
Trade, services and investment sector & 121 \\
Total & $\mathbf{4 2 7}$ \\
Observation periods (2013 to 2016 or four years) & 4 \\
\hline Firm-year observations & $\mathbf{1 , 7 0 8}$ \\
\hline
\end{tabular}

Source: IDX (2016)

\section{Conclusion}

This paper proposes a conceptual framework to test the effectiveness of audit committee through meetings, expertise and meeting attendance after the adoption of new codes of guidelines for the work of audit committees in Indonesia. It is expected that this study will increase the existing knowledge by measuring the effect of audit committee effectiveness through the aforementioned factors on earnings quality. In a nutshell, it expected that future empirical studies that adopted this model in Indonesia will provide a highlight on the impact of meetings, expertise and meeting attendance on earnings quality in Indonesian companies. Thus, understanding the effects of these three factors will provide a solution to overcome the earnings quality issues in Indonesia.

\section{References}

Adiguzel, H. (2013). Corporate Governance, Family Ownership and Earnings Management: Emerging Market Evidence. Accounting and Finance Research, 2(4), p17.

Alves, S. (2014). The Effect of Board Independence on the Earnings Quality: Evidence from Portuguese Listed Companies. Australasian Accounting Business \& Finance Journal, 8(3), 23.

Azzoz, M., Abdel, A. R., \&Khamees, B. A. (2016). The Impact of Corporate Governance Characteristics on Earnings Quality and Earnings Management: Evidence from Jordan. Jordan Journal of Business Administration, 12(1), 187 - 207.

Badolato, P. G., Donelson, D. C., \&Ege, M. (2014).Audit committee financial expertise and earnings management: The role of status.Journal of Accounting and Economics, 58(2), 208-230.

Bamahros, H. M., \& Wan-Hussin, W. N. (2015).Types of institutional investors and earnings management in Malaysia.Advanced Science Letters, 21(6), 2003-2006.

Bala, H., \& Kumai, B. (2015).Audit committee characteristics and earnings quality of listed food and beverages firms in Nigeria.International Journal of Accounting, 2(8), 216-227.

Baxter, P., \& Cotter, J. (2009).Audit committees and earnings quality.Accounting \& Finance, 49(2), 267-290.

Beasley, M.S. (1996). An Empirical Analysis of the Relation Between the Board of Director Composition and Financial Statement Fraud. The Accounting Review, Vol. 71, No. 4: pp. 443-465.

Carcello, J. V., Hollingsworth, C. W., Klein, A., \& Neal, T. L. (2006).Audit committee financial expertise, competing corporate governance mechanisms, and earnings management. Competing Corporate Governance Mechanisms, and Earnings Management (February 2006)

Chandrasegaram, R., Rahimansa, M. R., Rahman, S. K., Abdullah, S., \& Mat, N. N. (2013). Impact of Audit Committee Characteristics on Earnings Management in Malaysian Public Listed Companies.International Journal of Finance and Accounting, 2(2), 114-119.

Chang, J. C., \& Sun, H. L. (2010). Does the disclosure of corporate governance structures affect firms' earnings quality? Review of Accounting and Finance, 9(3), 212-243. 
Cohen, J., Krishnamoorthy, G., \& Wright, A. (2017). Enterprise risk management and the financial reporting process: The experiences of audit committee members, CFOs, and external auditors. Contemporary Accounting Research.

Dechow, P., Ge, W., \&Schrand, C. (2010). Understanding earnings quality: A review of the proxies, their determinants and their consequences. Journal of Accounting and Economics, 50(2), 344401.

Dhaliwal, D., Li, O. Z., Tsang, A., \& Yang, Y. G. (2014). Corporate social responsibility disclosure and the cost of equity capital: The roles of stakeholder orientation and financial transparency. Journal of Accounting and Public Policy, 33(4), 328-355.

Donaggio, A. (2014). Limitations of Legal Transplants and Convergence to Corporate Governance Practices in Emerging Markets: The Brazilian Case. In Corporate Governance in Emerging Markets (pp. 465-484).Springer Berlin Heidelberg.

Ewert, R., \&Wagenhofer, A. (2013).Accounting standards, earnings management, and earnings quality.

Fan, J. P., \& Wang, T. J. (2005). Do external auditors perform a corporate governance role in emerging markets? Evidence from East Asia. Journal of Accounting research, 43(1), 35-72.

García, L. S., Barbadillo, E. R., \& Pérez, M. O. (2010). Audit committee and internal audit and the quality of earnings: empirical evidence from Spanish companies. Journal of Management \& Governance, 16(2), 305-331.

Hamdan, A. M. M., Mushtaha, S. M. S., \& Al-Sartawi, A. A. M. (2013). The audit committee characteristics and earnings quality: Evidence from Jordan. Australasian Accounting Business \& Finance Journal, 7(4), 51.

Jensen, M. C., \&Meckling, W. H. (1976). Theory of the firm: Managerial behavior, agency costs and ownership structure. Journal of Financial Economics, 3(4), 305-360.

Lo, A. W., Wong, R. M., \& Firth, M. (2010). Can corporate governance deter management from manipulating earnings? Evidence from related-party sales transactions in China.Journal of Corporate Finance, 16(2), 225-235.

Luchs, C., Stuebs, M., \& Sun, L. (2009).Corporate Reputation and Earnings Quality.Journal of Applied Business Research,25(4), 47-54.

McKnight, P. J., \& Weir, C. (2009). Agency costs, corporate governance mechanisms and ownership structure in large UK publicly quoted companies: A panel data analysis. The Quarterly Review of Economics and Finance, 49(2), 139-158.

Martínez-Ferrero, J., Garcia-Sanchez, I. M., \&Cuadrado-Ballesteros, B. (2015).Effect of financial reporting quality on sustainability information disclosure.Corporate Social Responsibility and Environmental Management, 22(1), 45-64

Marra, A., Mazzola, P., \&Prencipe, A. (2011).Board monitoring and earnings management pre-and post-IFRS.The International Journal of Accounting, 46(2), 205-230.

Menon, K., \& Williams, J. D. (1994).The use of audit committees for monitoring.Journal of Accounting and Public Policy, 13(2), 121-139.

Mohamad, M, M, S., Rashid,,H,,M,,A., Shawtari, F,A,M., (2012). Corporate governance and earnings management in Malaysian government linked companies. Asian Review of Accounting, 20 (3), $241-258$.

Musa, N, D, Kamardin,, H and Abdul Malak, S, S, D., (2017). audit committee attendance and earnings management in nigeria. Asian Journal of Multidisciplinary Studies, 5(3), 47-54.

Nelson, M. W., \& Skinner, D. J. (2013). How should we think about earnings quality? A discussion of "Earnings quality: Evidence from the field". Journal of Accounting and Economics, 56(2), 34-41.

Ormin, K., Tuta, B. I., \& Shadrach, M. M. Audit Committee Independence, Meeting Frequency, Attendance and Financial Reporting Quality of Listed Deposit Money Banks in Nigeria.Research Journal of Finance and Accounting, 6 (18), 183 -190.

Qi, B., \& Tian, G. (2012). The impact of Audit Committees' personal characteristics on earnings management: Evidence from China. Journal of Applied Business Research, 28(6), 1331. 
Rickling, M. (2014).“Audit committee characteristics and repeatedly meeting-beating analyst forecasts".International Journal of Business 19 (2), 173-191.

Roberts, J., McNulty, T., and Stiles, P. (2005). Beyond agency conceptions of the work of nonExecutiveDirector: creating accountability in the boardroom. British Journal of Management 16 (1) 5-26.

RochmahIka, S., \&MohdGhazali, N. A. (2012).Audit committee effectiveness and timeliness of reporting: Indonesian evidence.Managerial Auditing Journal, 27(4), 403-424.

Rusmin,( 2011). Internal governance and monitoring and earning quality.JurnalBisnisdanAkuntansi, 13(3),145-162.

Saenz Gonzalez, J., \&García-Meca, E. (2014). Does Corporate Governance Influence Earnings Management in Latin American Markets? Journal of Business Ethics, 121(3), 419-440.

Saleh, N. M., Iskandar, T. M., \&Rahmat, M. M. (2007). Audit committee characteristics and earnings management: evidence from Malaysia. Asian Review of Accounting, 15(2),147-163.

Salleh, N. M. Z. N., \&Haat, M. H. C. (2014).Audit committee and earnings management: pre-and post MCCG.International Review of Management and Business Research, 3(1), 307-318.

Schipper, K., \& Vincent, L. (2003).Earnings quality.Accounting Horizons, 17, 97-110.

Sharma, V. D., \&Kuang, C. (2014). Voluntary audit committee characteristics, incentives, and aggressive earnings management: evidence from New Zealand. International Journal of Auditing, 18(1), 76-89.

Soliman, M. M., \&Ragab, A. A. (2014). Audit committee effectiveness, audit quality and earnings management: an empirical study of the listed companies in Egypt. Research Journal of Finance and Accounting, 5(2), 155-166.

Sun, J, Lan,G Liu, J, (2014). Independent audit committee characteristics and real earnings Management. Managerial Auditing Journal, 29 (2), 153 - 172.

Vafeas, N. (1999). Board meeting frequency and firm performance.Journal of Financial Economics, 53(1), 113-142.

Yusof, M. A. M. (2010). "Does audit committee constraint discretionary accruals in MESDAQ listed companies?”.International Journal of Business and Social Science, 1 (3), 124-136.

Wang, Y., Wu, L., \& Yang, Y. (2009). Does the stock market affect firm investment in China? A price informativeness perspective.Journal of Banking and Finance, 33(1).

Weir, C., Laing, D., \& McKnight, P. J. (2002). Internal and external governance mechanisms: their impact on the performance of large UK public companies. Journal of Business Finance \& Accounting, 29(5-6), 579-611. 
